\title{
Deguelin exerts anticancer activity of human gastric cancer MGC-803 and MKN-45 cells in vitro
}

\author{
WEN KANG $^{1 *}$, XIAO ZHENG ${ }^{1 *}$, PING WANG ${ }^{2}$ and SHANYU GUO ${ }^{1}$ \\ ${ }^{1}$ Department of General Surgery, Shanghai Ninth People's Hospital, Shanghai Jiaotong University School of Medicine, \\ Shanghai 200011; ${ }^{2}$ Department of Pathology, College of Basic Medical Sciences, Zhejiang Chinese \\ Medical University, Hangzhou, Zhejiang 310053, P.R. China
}

Received December 5, 2016; Accepted February 5, 2018

DOI: $10.3892 /$ ijmm.2018.3532

\begin{abstract}
During the pathogenesis of gastric cancer, Akt signaling is considered as a pivotal inducer of gastric cancer development. Here we report the identification of anticancer activities of deguelin, a natural agent that inhibits Akt signaling. When applied to MGC-803 and MKN-45 cells, deguelin suppressed the proliferation and arrested cell cycle by $\mathrm{p} 21$-mediated inhibition of cyclin E. We further present in vitro evidence that deguelin promoted apoptosis of cancer cells by decreasing the phospho-Akt signaling and affecting expression of the apoptosis-associated genes Bax and Bcl-2. Additionally, deguelin was found to suppress the migration and invasion of gastric cancer cells. Taken together, these results indicated that deguelin exerted anticancer activity of human gastric cancer MGC-803 and MKN-45 cells in vitro.
\end{abstract}

\section{Introduction}

Gastric cancer is biologically aggressive and one of the leading causes of cancer-related deaths (1). Although multiple therapeutic modalities exist, including surgical excision, radiation therapy and chemotherapy, the clinical results remain unsatisfactory due to gastric cancer often being diagnosed in an advanced stage or metastatic stage (2). Hence, great research efforts have been explored to exploit novel molecular markers

Correspondence to: Dr Shanyu Guo, Department of General Surgery, Shanghai Ninth People's Hospital, Shanghai Jiaotong University School of Medicine, 639 Zhizaoju Road, Shanghai 200011, P.R. China

E-mail: guoshyu1@163.com

Dr Ping Wang, Department of Pathology, College of Basic Medical Sciences, Zhejiang Chinese Medical University, 548 Binwen Road, Hangzhou, Zhejiang 310053, P.R. China

E-mail: wangping897@163.com

\section{${ }^{*}$ Co-first author}

Key words: deguelin, gastric cancer, proliferation, apoptosis, migration, invasion and detailed molecular mechanisms contributing to improving diagnostic and therapeutic management of gastric cancer.

The molecular basis of gastric cancer is complicated and involvestheinteractionsbetweengeneticandenvironmentalfactors. Among these etiologies, phosphoinositide-3 kinase (PI3K)/protein kinase B (Akt) pathway is believed to be important in gastric cancer development (3-5). Tian et al demonstrated that the expression of Akt and PI3K were remarkably higher in tumor tissue than that in normal tissue (3). In addition, Ye et al found that PI3K/Akt signaling pathway plays a crucial role in the formation and progression of gastric cancer (4). Simultaneously, phosphorylated-Akt expression significantly correlated with a poor prognosis (5). Therefore, PI3K/Akt pathway may represent a considerable therapeutic target for gastric cancer.

Deguelin, a natural component derived from leguminous plants, has been reported to prevent breast cancer (6), tobacco carcinogeninduced lung carcinogenesis (7), prostate cancer (8) and squamous cancer (9) by blocking Akt activation. Many studies have demonstrated that deguelin exerts its anticancer effect by inhibiting cell viability, cell growth, migration and invasion, inducing apoptosis, targeting cell cycle arrest and anti-angiogenesis $(7,10,11)$.

Therefore, deguelin may provide an alternative potential approach for gastric cancer treatment. Here, we investigated that deguelin not only inhibited the proliferation, invasion, migration but also induced apoptosis in gastric cancer MGC-803 and MKN-45 cells in vitro.

\section{Materials and methods}

Cell culture and reagents. Human gastric cancer cell lines MGC-803 and MKN-45 were purchased from Shanghai institute of Cell Biology, Chinese Academy of Sciences and cultured in RPMI-1640 medium with 10\% fetal bovine serum (FBS) and $1 \%$ penicillin-streptomycin (Gibco, Grand Island, NY, USA) under a humidified $5 \% \mathrm{CO}_{2}$ atmosphere at $37^{\circ} \mathrm{C}$. Deguelin (MedChem Express, Monmouth Junction, NJ, USA) was dissolved in dimethyl sulfoxide (DMSO) at concentration of $10 \mathrm{mM}$ as stock solution and stored at $-20^{\circ} \mathrm{C}$. Before using, deguelin was diluted directly to the desired dose with an identical final concentration of DMSO.

Cell counting kit-8 (CCK-8) cell proliferation assay. CCK-8 (Dojindo, Kumamoto, Japan) assay was used to determine 
the inhibitory effect of deguelin on the proliferation of two cancer cell types. The MGC-803 (3x103/well) and MKN-45 ( $5 \times 10^{3} /$ well) cells were plated in 96-well plates with $200 \mu \mathrm{l}$ of medium. Before the cells were treated with various concentrations of deguelin $(0,1,5,10,25$ and $50 \mu \mathrm{M})$, they were starved in serum-free medium for $24 \mathrm{~h}$ to allow for cell synchronization, and then tested at $72 \mathrm{~h}$. At the testing time-point, $10 \mu \mathrm{l}$ of sterile CCK-8 solution was added to each well and incubated for an additional $1.5 \mathrm{~h}$ at $37^{\circ} \mathrm{C}$. The optical density values at $450 \mathrm{~nm}$ were measured with a microplate reader (Thermo Scientific, Waltham, MA, USA). The inhibitory rate was calculated using the following formula: Inhibitory rate $(\%)=\left(\mathrm{A}_{450}\right.$ of control cells- $\mathrm{A}_{450}$ of treated cells $) /\left(\mathrm{A}_{450}\right.$ of control cells $) \times 100 \%$. The assays were repeated using six cell samples. In addition, for the cell viability test after treatment of deguelin, the MGC-803 $\left(1.5 \times 10^{3} /\right.$ well $)$ and MKN-45 $\left(2.5 \times 10^{3} /\right.$ well $)$ cells were plated in 96-well plates with the medium of $200 \mu 1$ and incubated with various concentrations of deguelin $(0,1,10$ and $25 \mu \mathrm{M})$, then tested using CCK-8 assay at days 1, 2, 3 and 4.

Morphology observation. After treated with deguelin $(0,1,10$ and $25 \mu \mathrm{mol} / \mathrm{l})$ for $48 \mathrm{~h}, \mathrm{MGC}-803$ and MKN-45 cells were observed under an inverted phase contrast microscope to determine their morphology changes.

Cell cycle analysis. After deguelin treatment for $48 \mathrm{~h}$, cells were collected, fixed in $70 \%$ ethanol and incubated at $4{ }^{\circ} \mathrm{C}$ overnight. Cells were then centrifuged and stained in ice-cold phosphate-buffered saline (PBS) solution containing $100 \mu \mathrm{g} / \mathrm{ml}$ propidium iodide (PI), $0.1 \%$ Triton X-100, and $1 \mathrm{mg} / \mathrm{ml}$ RNase for $0.5 \mathrm{~h}$. After washing, the samples were analyzed by flow cytometry (Beckman Coulter, Brea, CA, USA).

Annexin V/FITC-PI assay. The apoptotic assays were performed by an Annexin V-FITC/PI apoptosis detection kit and detected as the manufacturer's instructions (Miltenyi Biotec, Bergisch Gladbach, Germany). Briefly, the $10^{6}$ cells were washed using $500 \mu \mathrm{l}$ binding buffer, centrifuged at $300 \mathrm{x} \mathrm{g}$ and stained with $10 \mu \mathrm{l}$ Annexin V-FITC solution in room temperature for $30 \mathrm{~min}$. Before testing, $5 \mu \mathrm{l}$ PI solution was added to each sample. The apoptosis rate was evaluated by flow cytometry. At least 10,000 cells for each sample was analyzed. The analyses were repeated in three cell samples.

Real-time quantitative PCR. Total RNAs from control and deguelin-treated cells were extracted by TRIzol reagent (Invitrogen, Carlsbad, CA, USA) and reverse translated with AMV reverse transcriptase (Promega, Madison, WI, USA). To synthesize complementary DNA, $2 \mu \mathrm{g}$ total RNA per sample was added to the reaction system of a final volume of $20 \mu \mathrm{l}$ containing $4 \mu \mathrm{l} 5 \mathrm{X}$ buffer, $2 \mu \mathrm{ldNTP}, 1 \mu \mathrm{l}$ oligo(dT), $0.5 \mu \mathrm{l}$ RNase inhibitor, $0.5 \mu \mathrm{l}$ AMV reverse transcriptase and $\mathrm{dd}_{2} \mathrm{O}$ to meet the final volume. After incubated at $30^{\circ} \mathrm{C}$ for $10 \mathrm{~min}$, $45^{\circ} \mathrm{C}$ for $60 \mathrm{~min}, 98^{\circ} \mathrm{C}$ for $5 \mathrm{~min}$ and $5^{\circ} \mathrm{C}$ for $5 \mathrm{~min}$, the amplified complementary DNA (cDNA) products were mixed with Power SYBR-Green PCR master mix (Applied Biosystems, Foster City, CA, USA). Quantitative polymerase chain reaction (qPCR) was conducted using a real-time thermal cycler (Stratagene, La Jolla, CA, USA). The glyceraldehyde-3-phosphate dehydrogenase $(G A P D H)$ cDNA content was used to normalize with cDNA, and the comparative $\mathrm{Ct}$ method was used to analyze data. The primers for real-time qPCR analysis are shown in Table I. Each assay was performed in triplicate and repeated in three cell samples.

Western blot analysis. Two different gastric cell lines were isolated after $6 \mathrm{~h}$ of incubation in the absence or different concentration of deguelin. Cells were scraped in RIPA lysis buffer and the protein content of cellular extracts were quantified by BCA assay. For western blot analysis, the prepared protein was resolved by sodium dodecyl sulfate-polyacrylamide gel electrophoresis (SDS-PAGE), transferred to PVDF membranes and incubated with the appropriate antibodies. For estimation of $\mathrm{p}$-Akt/total-Akt protein, we used two different specific antibodies: monoclonal anti-p-Akt and monoclonal anti-total-Akt (both from Cell Signaling Technology, Beverly, MA, USA). The blots were probed with $\beta$-actin antibody (Cell Signaling Technology) for equal loading control. The secondary antibody was goat anti-rabbit HRP-conjugated antibody (Jackson ImmunoResearch, West Grove, PA, USA). Immunoreactive proteins were detected by the enhanced chemiluminescent (ECL) protocol (Amersham Biosciences, Piscataway, NJ, USA).

4',6-Diamidino-2-phenylindole (DAPI) staining. MGC-803 and MKN-45 cells were cultured as described, and then treated with various concentrations of deguelin for $48 \mathrm{~h}$. Apoptosis was further determined by nucleus morphology using DAPI staining (Sigma-Aldrich, St. Louis, MO, USA). After being fixed and stained with DAPI, the cells were examined under a fluorescent microscope (Olympus, Tokyo, Japan).

Cell migration assay. The MGC-803 and MKN-45 cells at a density of $2 \times 10^{5}$ cells/well were cultured in 6-well plates. When reaching $90 \%$ confluence, the cells were scratched by a sterile yellow $200 \mu 1$ pipette tip and then washed three times with PBS. The cells were then placed in fresh RPMI-1640 medium containing $1 \%$ FBS with treatment of deguelin or DMSO for $24 \mathrm{~h}$. Five random fields were selected and photographed with an inverted microscope, respectively.

Cell invasion assay. The ability of deguelin to inhibit cell invasion was tested using Transwell assay. The Transwell is in 24-well plate with an insert of $8-\mu \mathrm{m}$ pore size polyethylene terephthalate membrane (Corning Life Sciences, Tewksbury, MA, USA). The cells were starved in serum-free medium overnight, then trypsinized and resuspended in serum-free medium. The cells at a density of $6 \times 10^{4}$ cells/well were seeded in the upper Transwell chamber which was coated with Matrigel (BD Biosciences, Bedford, MA USA), then incubated with DMSO or deguelin (1 and $10 \mu \mathrm{M})$ for $24 \mathrm{~h}$, and $500 \mu \mathrm{l}$ of complete growth medium was added to the bottom. Cells on the upper membrane were wiped off with a cotton swab. Invaded cells on the lower membrane were fixed with 4\% paraformaldehyde, stained with DAPI and three random fields were counted under a fluorescent inverted phase contrast microscope at x200 magnification.

Statistical analysis. All data were expressed as mean \pm standard deviation (SD). Student's t test was used to analysis the 
Table I. Primers used in quantitative PCR analysis.

\begin{tabular}{|c|c|c|c|}
\hline Gene & $\begin{array}{l}\text { Primer sequence }\left(5^{\prime}-3^{\prime}\right) \\
\text { temperature }\left({ }^{\circ} \mathrm{C}\right)\end{array}$ & $\begin{array}{l}\text { Annealing } \\
\text { size (bp) }\end{array}$ & Product \\
\hline $\operatorname{Bax}$ & $\begin{array}{l}\text { Sense: } \quad \text { TGCTTCAGGGTTTCATCCAG } \\
\text { Antisense: GGCGCCAATCATCCTCTG }\end{array}$ & 58 & 170 \\
\hline $\mathrm{Bcl}-2$ & $\begin{array}{l}\text { Sense: } \\
\text { Antisense: }\end{array}$ & 58 & 192 \\
\hline Cyclin E1 & $\begin{array}{l}\text { Sense: } \\
\text { Antisense: } \\
\text { CAGTTTTGGATTTAAGTCCCCTG } \\
\end{array}$ & 58 & 326 \\
\hline p21 & $\begin{array}{ll}\text { Sense: } & \text { TCCAGCGACCTTCCTCATCCAC } \\
\text { Antisense: } & \text { TCCATAGCCTCTACTGCCACCATC }\end{array}$ & 58 & 108 \\
\hline GAPDH & $\begin{array}{ll}\text { Sense: } & \text { TCACCATCTTCCAGGAGCG } \\
\text { Antisense: } & \text { CTGCTTCACCACCTTCTTGA }\end{array}$ & 58 & 572 \\
\hline
\end{tabular}

GAPDH, glyceraldehyde-3-phosphate dehydrogenase.

difference between the deguelin-treated and control groups. The analysis was conducted with the statistical software SPSS 22 (SPSS Inc., Chicago, IL, USA). P<0.05 was considered statistically significant.

\section{Results}

Inhibitory effect of deguelin on the growth of MGC-803 and MKN-45 cells. CCK-8 assay showed inhibitory effect of deguelin on the growth of MGC-803 and MKN-45 cells. As shown in Fig. 1A and B, after various doses (1, 5, $10,25$ and $50 \mu \mathrm{M})$ of deguelin treatment on MGC-803 and MKN-45 cells for $72 \mathrm{~h}$, the IR (inhibitory rate) of MGC-803 cells was $8.56 \pm 0.06,12.20 \pm 0.07,44.06 \pm 0.10,81.00 \pm 0.01$ and $86.66 \pm 0.01 \%$, respectively and the IR of MKN-45 cells was $19.68 \pm 0.03,32.83 \pm 0.03,48.98 \pm 0.03,66.48 \pm 0.01$ and $83.33 \pm 0.01 \%$, respectively. $\mathrm{The}^{\mathrm{IC}_{50}}(72 \mathrm{~h})$ value for MGC-803 and MKN-45 was 11.83 and $9.33 \mu \mathrm{M}$, respectively. As the dose of deguelin increased, the IR of MGC-803 and MKN-45 cells improved gradually.

The effect of deguelin on the cell morphology. As the $\mathrm{IC}_{50}$ described above, doses of 1,10 and $25 \mu \mathrm{M}$ deguelin were chosen to perform the rest of the assays. As shown in Fig. 1C and D, after incubated with different concentrations of deguelin $(1$, 10 and $25 \mu \mathrm{M}$ ) for $48 \mathrm{~h}$, the number of deguelin-treated cells was less than that of blank control cells. In contrast to the cells of control group which exhibited normal features with typical adherent, membrane intact morphology, deguelin treatment groups showed obvious apoptotic morphology with membrane distorted morphology with dose-dependent severity.

Deguelin inhibited cell proliferation and arrested the cell cycle of MGC-803 and MKN-45 cells. Deguelin treatment resulted in a dose- and time-dependent decrease in cell viability (Fig. 2A and B). To address whether the inhibitory effect of deguelin on the growth of cancer cells was accompanied by blocking the cell cycle, FCM assay was performed. Previous experiments suggested that a very high death rate occurred in $25 \mu \mathrm{M}$ deguelin-treated cells and therefore we chose 1 and $10 \mu \mathrm{M}$ deguelin treatment group to conduct the cell cycle assay. The assay indicated that deguelin altered the cell cycle distribution after $48 \mathrm{~h}$ treatment in both tested cell lines. For MGC-803 cells, deguelin induced cells cycle arrest at $\mathrm{G}_{0} / \mathrm{G}_{1}$ phase (Fig. 2C and D). Compared with control group $(57.27 \pm 1.48 \%)$, the percentage of $\mathrm{G}_{0} / \mathrm{G}_{1}$ phase cells of deguelin treatment groups $(67.53 \pm 1.72 \%$ at $1 \mu \mathrm{M}, 72.1 \pm 4.10 \%$ at $10 \mu \mathrm{M})$ increased $(\mathrm{P}<0.05)$, and $\mathrm{S}$ and $\mathrm{G}_{2} / \mathrm{M}$ phases decreased accordingly. For MKN-45 cells, low dose of deguelin induced cell cycle arrest at $\mathrm{S}$ phase, while high dose of deguelin induced cell cycle arrest at $\mathrm{G}_{2} / \mathrm{M}$ phase (Fig. $2 \mathrm{E}$ and $\mathrm{F}$ ). Compared with control group $(22.53 \pm 1.11 \%$ at $\mathrm{S}$ phase, $11.60 \pm 0.90 \%$ at $\mathrm{G}_{2} / \mathrm{M}$ phase), the percentage of $\mathrm{S}$ phase cells of low dosetreated group $(34.27 \pm 1.31 \%)$ increased $(\mathrm{P}<0.05)$, and the percentage of $\mathrm{G}_{2} / \mathrm{M}$ phase cells of high dose-treated group $(32.93 \pm 2.44 \%)$ increased $(\mathrm{P}<0.01)$.

Deguelin promotes apoptotic effects on cultured MGC-803 and $M K N-45$ cells. Apoptosis was assessed in MGC-803 and MKN-45 cells after treatment with 1,10 and $25 \mu \mathrm{M}$ deguelin for $48 \mathrm{~h}$. The early $(10.87 \pm 0.46 \%$ at $1 \mu \mathrm{M}, 20.20 \pm 3.21 \%$ at $10 \mu \mathrm{M}$ and $52.70 \pm 4.88 \%$ at $25 \mu \mathrm{M})$, late $(5.17 \pm 1.28$ at $1 \mu \mathrm{M}$, $17.60 \pm 4.25 \%$ at $10 \mu \mathrm{M}$ and $22.90 \pm 4.58 \%$ at $25 \mu \mathrm{M})$ and total $(16.03 \pm 1.60 \%$ at $1 \mu \mathrm{M}, 37.80 \pm 7.02 \%$ at $10 \mu \mathrm{M}$ and $75.60 \pm 7.08 \%$ at $25 \mu \mathrm{M})$ apoptosis rates were increased significantly in MGC-803 cells compared with control $(8.03 \pm 1.31 \%$ of early, $4.60 \pm 0.50 \%$ of late and $12.63 \pm 1.76 \%$ of total apoptosis rate) (Fig. 3A and B). Similarly, the early (19.20 \pm 0.79 at $1 \mu \mathrm{M}, 39.13 \pm 4.01 \%$ at $10 \mu \mathrm{M}$ and $62.63 \pm 2.00 \%$ at $25 \mu \mathrm{M})$, late $(3.73 \pm 0.66$ at $1 \mu \mathrm{M}, 18.57 \pm 2.36 \%$ at $10 \mu \mathrm{M}$ and $29.23 \pm 1.70 \%$ at $25 \mu \mathrm{M})$ and total $(22.93 \pm 0.90$ at $1 \mu \mathrm{M}, 57.70 \pm 6.33 \%$ at $10 \mu \mathrm{M}$ and $91.87 \pm 3.37 \%$ at $25 \mu \mathrm{M})$ apoptosis rates were also increased in $\mathrm{MKN}-45$ cells compared with control $(2.00 \pm 0.28 \%$ of early, $1.07 \pm 0.33 \%$ of late and $3.07 \pm 0.46 \%$ of total apoptosis rate) (Fig. 4A and B). This suggested that deguelin prominently induced apoptosis in gastric cancer cells. DAPI staining showed that many apoptotic bodies with condensed chromatin and apoptotic nucleus fragmentations were observed in 


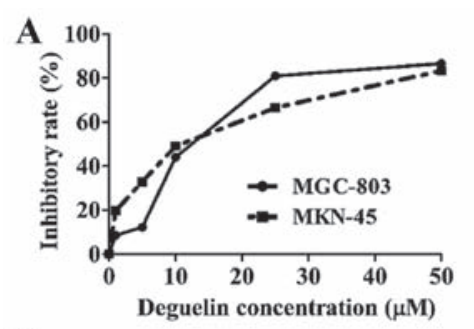

B

\begin{tabular}{rrrr}
\hline \multirow{2}{*}{ Group } & \multirow{2}{*}{$\mathrm{n}$} & \multicolumn{2}{c}{ Inhibitory rate } \\
\cline { 3 - 4 } & & \multicolumn{1}{c}{ MGC-803 } & MKN-45 \\
\hline $5 \mu \mathrm{M}$ & 5 & $8.56 \pm 0.06$ & $19.68 \pm 0.03$ \\
$10 \mu \mathrm{M}$ & 5 & $12.20 \pm 0.07$ & $32.83 \pm 0.03$ \\
$25 \mu \mathrm{M}$ & 5 & $44.06 \pm 0.10$ & $48.98 \pm 0.03$ \\
$50 \mu \mathrm{M}$ & 5 & $81.00 \pm 0.01$ & $66.48 \pm 0.01$ \\
& 5 & $86.66 \pm 0.01$ & $83.33 \pm 0.01$ \\
\hline
\end{tabular}
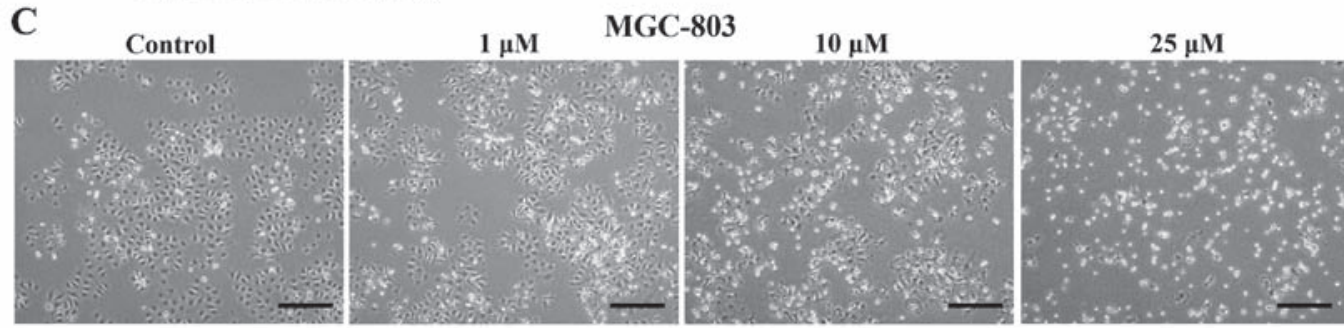

D
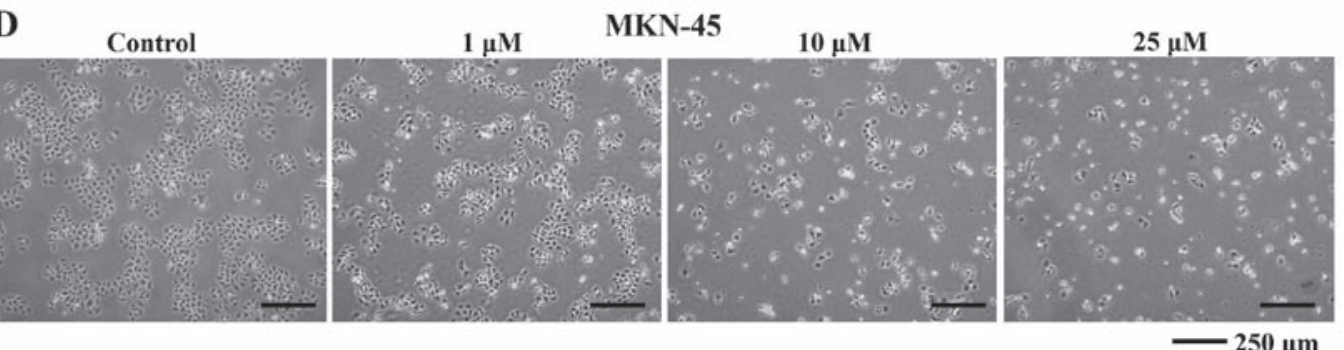

Figure 1. Inhibitory rates of deguelin on the growth of MGC-803 and MKN-45. Human gastric cancer MGC-803 and MKN-45 cells were incubated with 0 , $1,5,10,25$ and $50 \mu \mathrm{M}$ of deguelin for $72 \mathrm{~h}$, and then examined by cell counting kit-8 (CCK-8). (A and B) Effect of different concentration of deguelin on the inhibitory rate of MGC-803 and MKN-45. Deguelin induced cell morphological change and photographed by a phase-contrast microscope and decreased the total human gastric cancer (C) MGC-803 and (D) MKN-45 cells for $48 \mathrm{~h}$. Data represent mean \pm SD. Original magnification, $\mathrm{x} 100$. The bar represents $250 \mu \mathrm{m}$.

deguelin-treated cells ( 1 and $10 \mu \mathrm{M}$ for $48 \mathrm{~h}$ ), but almost none in untreated cells (Fig. 3C and 4C). Notably also, not only did deguelin reduce the proliferation of MGC-803 and MKN-45 cells, but also visibly induced apoptosis.

Relative gene and protein expression under the treatment of deguelin. Deguelin exerted its antitumor activity by inducing cell cycle arrest, apoptosis and inhibiting cell proliferation. Further experiments revealed the effect of deguelin on the apoptotic and proliferative gene expression. After treated in vitro with 1 and $10 \mu \mathrm{M}$ deguelin for $48 \mathrm{~h}$. Deguelin upregulated the gene expression of Bax (Fig. 5A and E) and downregulated that of $\mathrm{Bcl}-2$ (Fig. 5B and F) of MGC-803 and MKN-45 cells. The expression of Bax and Bcl-2 in MGC-803 and MKN-45 cells showed significant difference from the control cells $(\mathrm{P}<0.05$ for all) (Fig. 5A, B, E and F). The gene expression of cyclin E1 was downregulated and that of $p 21$ was upregulated dramatically in a dose-dependent manner. The expression of cyclin E1 and p21 of MGC-803 and MKN-45 cells showed significant difference from the control cells ( $\mathrm{P}<0.05$ for all) (Fig. 5C, D, G and H).

Demonstration of deguelin-induced apoptosis of cancer cells by mediating Akt signal pathway. To test Akt inhibition by deguelin, MGC-803 and MKN-45 cells were treated in vitro with 1 and $10 \mu \mathrm{M}$ deguelin for $6 \mathrm{~h}$. Consistent with previous studies in other tumor cells $(6,12,13)$, deguelin downregulated the expression of p-Akt (Fig. 5I). This result implied that deguelin induced apoptosis in gastric cells by downregulating Akt activity.
Deguelin inhibits the migration of MGC-803 and MKN-45 cells in vitro. To evaluate the effect of deguelin on a migration ability of MGC-803 and MKN-45 cells, wounded scratch assay was performed on both cell lines. The result showed that $24 \mathrm{~h}$ after scratching the cell migration of both cell lines was significantly inhibited by deguelin treatment (Fig. 6). MGC-803 and MKN-45 cells in the control group efficiently migrated into the scratched area (Fig. 6A and C). MGC-803 cells of the control group migrated $67.07 \pm 4.67 \%$ of the scratched area, whereas the $1 \mu \mathrm{M}$ deguelin-treated MGC-803 cells migrated $37.12 \pm 1.53 \%$ of the area $(\mathrm{P}<0.05)$ and the $10 \mu \mathrm{M}$ deguelin-treated MGC-803 cells migrated $31.69 \pm 0.81 \%$ of the area $(\mathrm{P}<0.05)$ (Fig. 6A and $\mathrm{B})$. Blank control MKN-45 cells migrated $29.78 \pm 3.67 \%$ of the area, whereas the MKN-45 cells of the $1 \mu \mathrm{M}$ and the $10 \mu \mathrm{M}$ deguelin-treated group, respectively, migrated $11.14 \pm 1.09$ and $3.96 \pm 1.03 \%$ of the area $(\mathrm{P}<0.05)$, and the migration rate was significantly lower in deguelin-treated group than that in blank control groups $(\mathrm{P}<0.05)$ (Fig. 6C and D).

Deguelin inhibits the invasion of MGC-803 and MKN-45 cells in vitro. Because the enhanced invasion properties of gastric cancer cells are the critical parameters in the development of gastric cancer, we wondered if deguelin would affect the cell behavior of MGC-803 and MKN-45 cells in vitro. Transwell chamber invasion assay results showed that, when compared

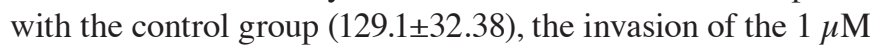
deguelin-treated MGC-803 cells $(36.89 \pm 9.67)$ and the $10 \mu \mathrm{M}$ deguelin-treated MGC-803 cells (12.67 \pm 2.62$)$ was significantly 
A

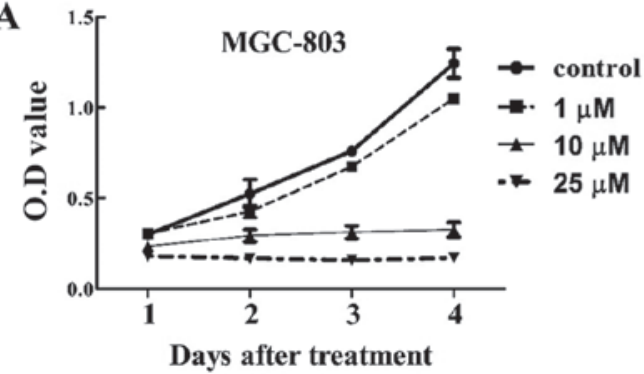

B

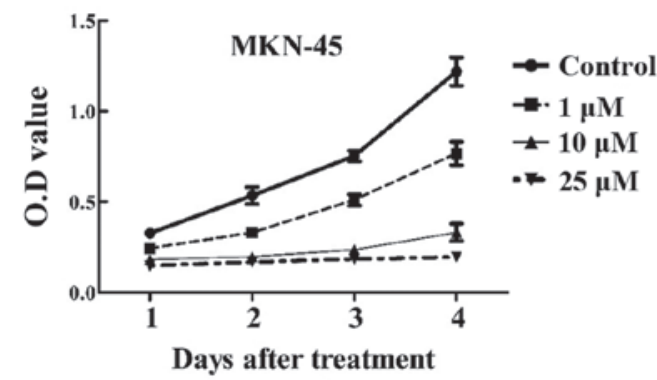

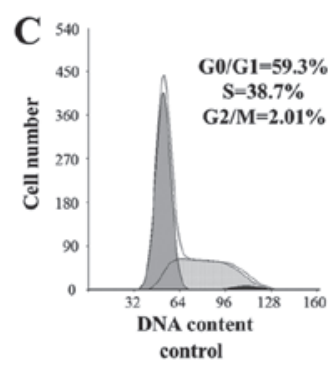

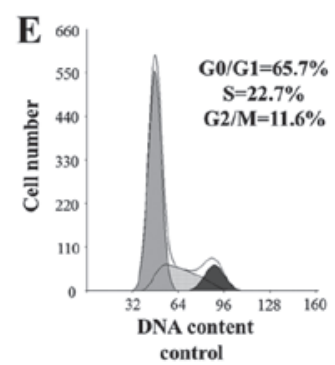

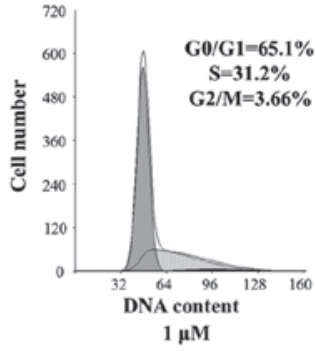

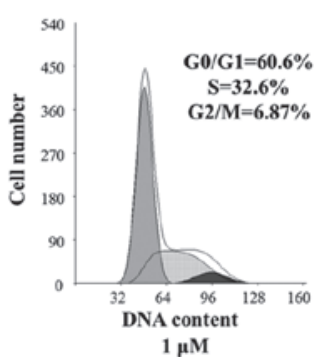

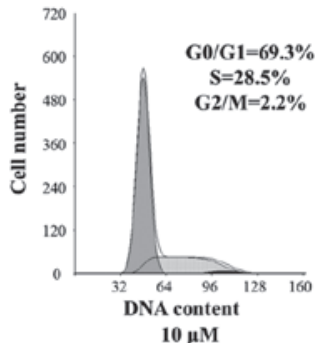
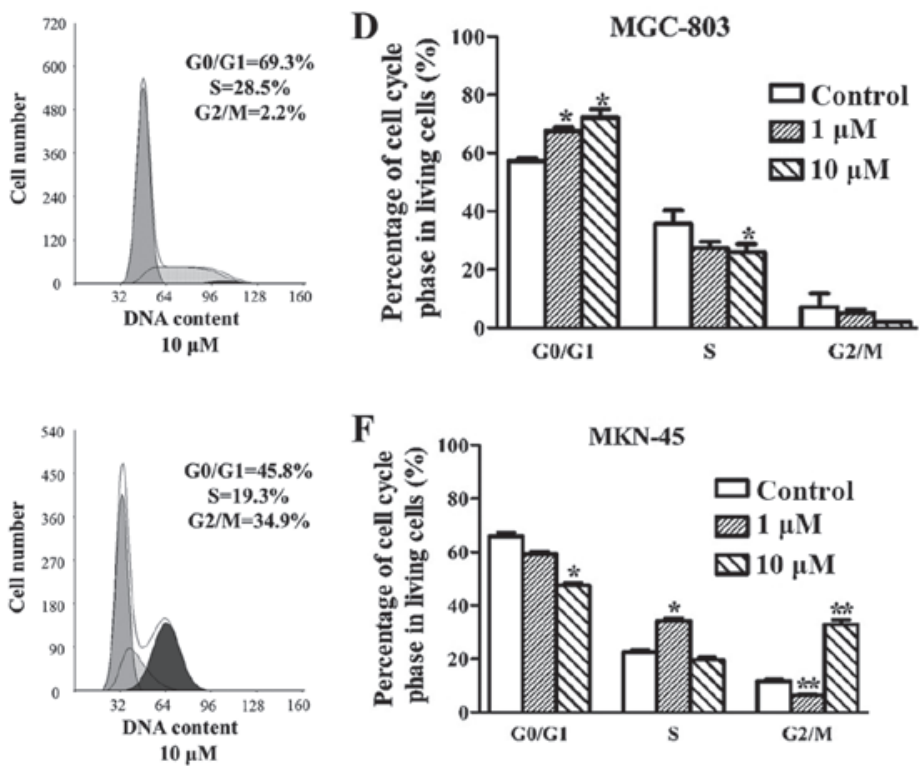

F

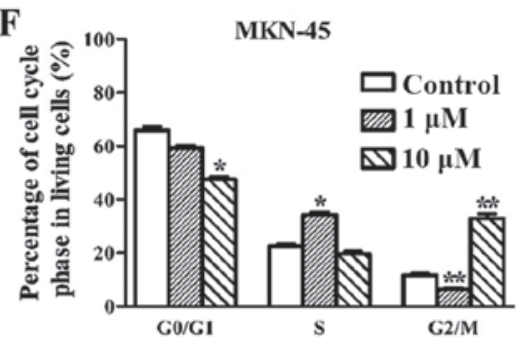

Figure 2. Treatment with deguelin inhibits gastric cancer cell proliferation. (A) The cell viabilities of (A) MGC-803 and (B) MKN-45 treated with or without deguelin $(1,10$ and $25 \mu \mathrm{M})$ were measured with a cell counting kit-8 (CCK-8) assay at days 1, 2, 3 and 4 . After treatment with deguelin for 48 h, gastric cell lines were subjected to flow cytometry analysis. (C and D) The effect of deguelin (1 and $10 \mu \mathrm{M})$ on the cell cycle profiles of MGC-803 cell lines was further evaluated. (E and F) The effect of deguelin $(1$ and $10 \mu \mathrm{M})$ on the cell cycle profiles of MKN-45 cell lines was further evaluated. All the experiments were repeated in three independent experiments. $G_{0} / G_{1}$, gap between end of $M$ phase and start of $S$ phase; $S$, DNA duplication phase; $G_{2}$, gap between end of $S$ phase and start of $\mathrm{M}$ phase; $\mathrm{M}$, mitosis. ${ }^{*} \mathrm{P}<0.05$, significant difference between control group and the experiment group; ${ }^{* *} \mathrm{P}<0.01$, significant difference between control group and the experiment group.

inhibited in a dose dependent manner $(\mathrm{P}<0.05)$ (Fig. 7A and $\mathrm{B})$. Deguelin (1 and $10 \mu \mathrm{M})$-treated MKN-45 cells exhibited much lower invasion ability compared to the blank control as evidenced by decreasing the number of cells migrated through the Matrigel (Fig. 7C and D). The invasion ability of MKN-45 cells treated with deguelin was dose-dependently decreased compared to that of DMSO treated MKN-45 cells $(13.90 \pm 6.76$ at $1 \mu \mathrm{M}$ and $5.60 \pm 1.85$ at $10 \mu \mathrm{M})$. These results indicated that deguelin was able to inhibit invasive ability of gastric cancer cells.

\section{Discussion}

Gastric cancer is a highly mortal malignancy with few effective therapies. Resulted from both genetic and environmental risk factors, such as gene mutations, cigarette smoking, helicobacter pylori and intake of salty and smoked food (14), gastric cancer is a heterogeneous and multifactorial disease. Most patients with aggressive gastric cancer fail to respond to surgery and radiotherapy, but they are sensitive to systemic chemotherapy as palliative care $(15,16)$. Therefore, the exploitation of potential alternative chemotherapy drug for gastric cancer is highly encouraging. Deguelin, a natural component of the flavonoid family products, has been used as a promising chemopreventive and therapeutic agent against various cancer cells $(13,17,18)$.

Deguelin has been reported to inhibit the proliferation of different cancer cells, including breast cancer cells, prostate cancer cells and lung squamous cell cancer cells $(6,8,9)$. This study revealed that proliferation of two different gastric cancer MGC-803 and MKN-45 cell lines were inhibited in a time- and dose-dependent manner by deguelin treatment (Fig. 1A and B). Some previous studies demonstrated the anti-proliferative effect of deguelin in different cancer cells was related to $G_{0} / G_{1}$ phase, $S$ phase or $G_{2} / M$ phase arrest $(10,19,20)$. Murillo et al found that deguelin promoted cell cycle arrest at $\mathrm{G}_{0} / \mathrm{G}_{1}$ phase in colon cancer cells (10). Our observations were in accord with an overall efficacy of deguelin in inducing a $G_{0} / G_{1}$ arrest in MGC-803 cells (Fig. 2C and D). In another study, premalignant and malignant human HBE cells treated with deguelin were observed to arrest at $\mathrm{G}_{2} / \mathrm{M}$ phase (7). Deguelin treatment of $\mathrm{MKN}-45$ cells resulted in $\mathrm{S}$ phase arrest at lower dose but $\mathrm{G}_{2} / \mathrm{M}$ phase arrest at higher dose (Fig. 2E and F). Indeed, more future studies are needed to identify the underlying mechanisms responsible for the action of deguelin to fully understand the seemingly puzzling role of this compound. 
A

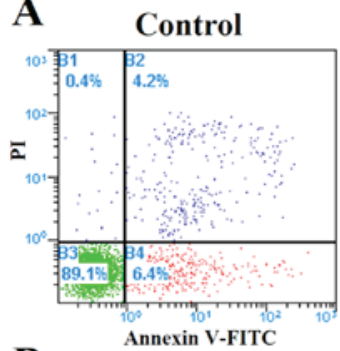

B

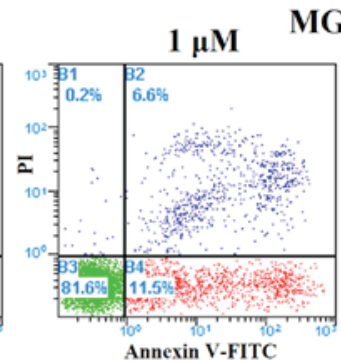

MGC-803

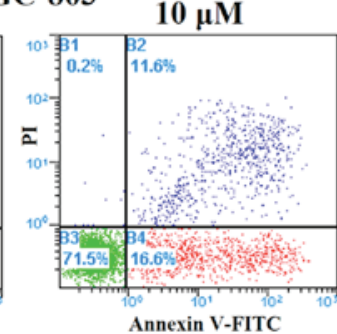

$25 \mu \mathrm{M}$

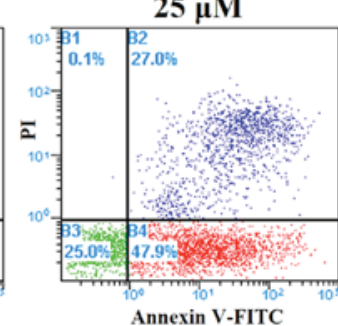

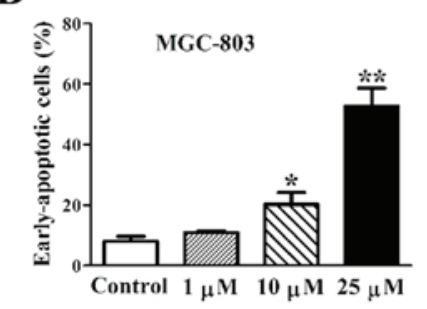
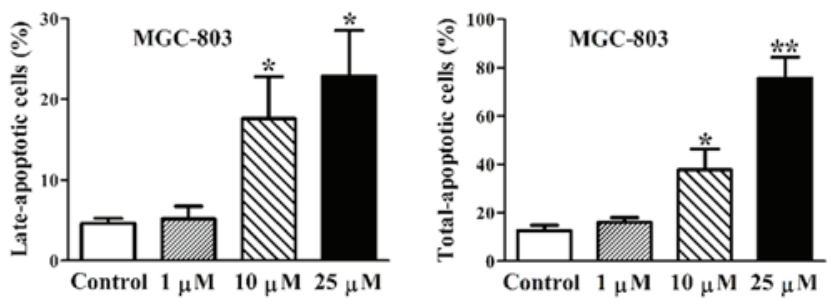

C
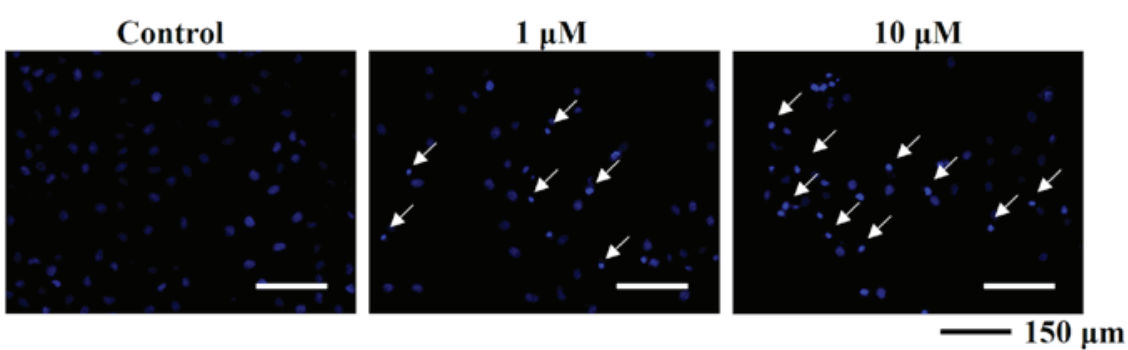

Figure 3. Deguelin triggered MGC-803 cell apoptosis. MGC-803 cells were exposed to complete medium containing indicated concentrations of deguelin (1, 10 and $25 \mu \mathrm{M}$ ) or control dimethyl sulfoxide (DMSO) for $48 \mathrm{~h}$. (A) Histograms show the percentages of viable, early and late apoptotic cells. The lower left quadrant represents the viable cells, the lower right quadrant represents the early apoptotic cells and the upper right quadrant represents the late apoptotic cells. (B) Quantification of early, late and total apoptotic cells induced by deguelin. (C) The impact of deguelin on cell apoptosis was further determined by 4',6-diamidino-2-phenylindole (DAPI) staining. DAPI nuclear staining indicated chromatin condensation. Arrows represent cells exhibiting apoptosis. The bar represents $150 \mu \mathrm{m} .{ }^{*} \mathrm{P}<0.05$ vs. the control cells. ${ }^{* *} \mathrm{P}<0.01$ vs. the control cells.

Abnormalities of cell cycle checkpoint regulators have been recognized as critical factors in the development of human cancers. Cyclin-dependent kinase (CDK) inhibitor p21 is a significant element in this regulatory cascade (21), and is shown to be associated with the prognosis of gastric cancer (22). p21 is a negative regulator of cell cycle progression (21). Overexpression of $\mathrm{p} 21$ has been identified as a crucial element resulting in cell cycle arrest at $G_{0} / G_{1}, S$ and $\mathrm{G}_{2} / \mathrm{M}$ phase (23). Radhakrishnan et al found that $\mathrm{p} 21$ was specifically associated with cyclin E, rather than cyclin D1, cyclin A, CDK4 or PCNA (23). Their finding are consistent with our results of increased expression of $p 21$ and decreased that of cyclin El after deguelin treatment in gastric cancer cells (Fig. 5C, D, G and H). These results suggested that p21-mediated inhibition of cyclin E could be one of the factors that is responsible for the proliferation inhibition and cell cycle arrest of gastric cancer with deguelin treatment.

Deguelin induced apoptosis in a wide array of cancer cell types in vitro, including lung squamous cell carcinoma cells, colon cancer cells and head and neck squamous cell cancer cell lines $(9,10,12)$. In the present study, we found that deguelin could induce apoptosis of gastric cancer MGC-803 and MKN-45 cell lines in vitro in a dose-dependent manner (Figs. 3 and 4), which is consistent with the effect of deguelin performed in other cancer cells $(9,11,12)$. The induction effect of apoptosis could be mediated by the suppression of various molecular pathways, such as
PI3K-Akt, IKK-IкB $\alpha-\mathrm{NF}-\kappa \mathrm{B}, \mathrm{EMT}, \mathrm{HSP} 90$ and AMPKmTOR-survivin pathways $(11,24,25)$. Among all the target pathways suggested for deguelin, the PI3K/Akt pathways have the strongest support for inducing cell apoptosis (7,26-29). As shown in Fig. 5, compared to the control group, phosphorylation of Akt was dramatically decreased by treatment with deguelin in a dose-dependent manner in both cell lines, suggesting that Akt pathway was responsible for deguelininduced cell apoptosis inhibition. To further corroborate the induced-apoptosis effects of deguelin, investigation on Akt and other pathways is still necessary.

In addition, based on the references of related literatures $(38,39)$, we assumed that another mechanism of deguelin induced-apoptosis in gastric cancer cells may be related to the mitochondria-mediated (also called the intrinsic) apoptosis pathways. Mitochondria-dependent apoptosis is mediated by the proteins of Bcl-2 family $(30,31)$, including antiapoptotic and proapoptotic proteins such as Bcl-2/xL and Bax/Bak (32-37). Bcl-2 family proteins change the mitochondrial membrane permeability required for the release of cytochrome $c(38)(39,40)$. Bcl-2 blocks the release of cytochrome $c$, whereas Bax localizes to mitochondria and enhances the release of cytochrome $c$, promotes nuclear fragmentation and induces cell death (41). Therefore, we measured the gene expression of $B c l-2$ and Bax to clarify the probable mechanism. Gene expression study by RT-qPCR has shown that deguelin persuaded apoptosis through intrinsic pathway 
A

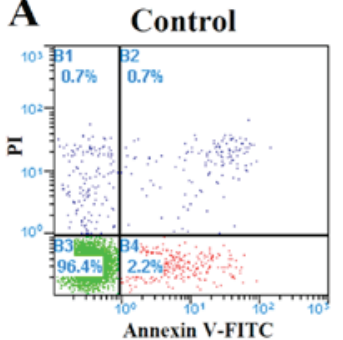

B

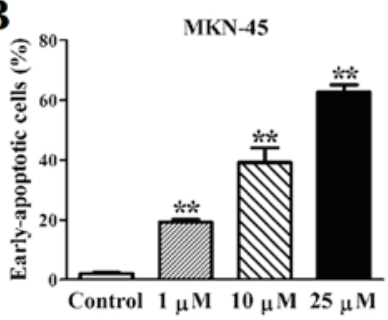

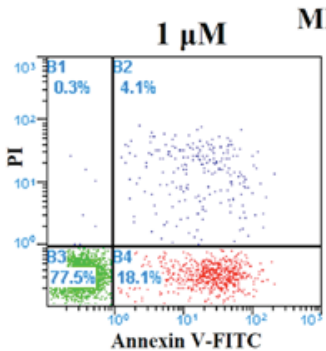

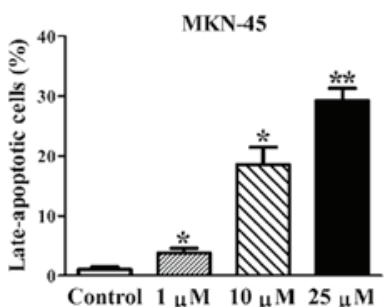

$10 \mu \mathrm{M}$

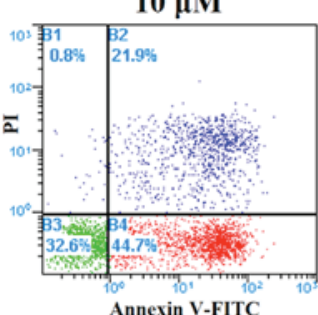

Annexin V-FITC

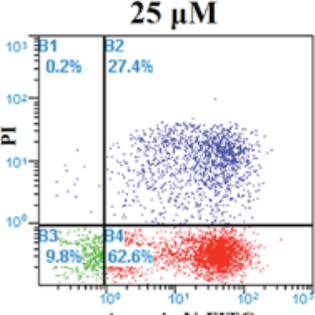

Annexin V-FITC

MKN-45

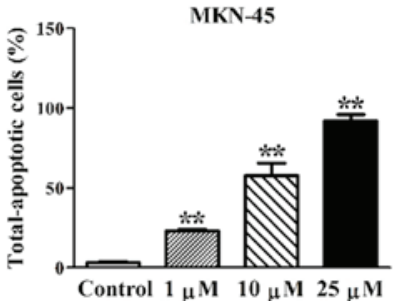

$1 \mu \mathrm{M}$

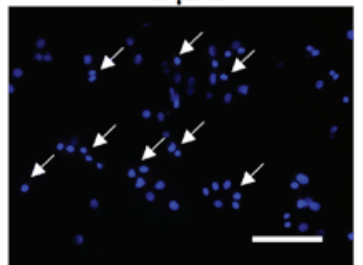

$10 \mu \mathrm{M}$

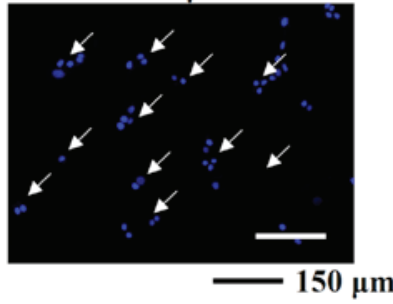

Figure 4. Deguelin triggers MKN-45 cells apoptosis. MKN-45 cells were exposed to complete medium containing indicated concentrations of deguelin (1, 10 and $25 \mu \mathrm{M}$ ) or control dimethyl sulfoxide (DMSO) for $48 \mathrm{~h}$. (A) Histograms show the percentages of viable, early and late apoptotic cells. The lower left quadrant represents the viable cells, the lower right quadrant represents the early apoptotic cells and the upper right quadrant represents the late apoptotic cells. (B) Quantification of early, late and total apoptotic cells induced by deguelin. (C) The impact of deguelin on cell apoptosis was further determined by 4',6-diamidino-2-phenylindole (DAPI) staining. DAPI nuclear staining indicated chromatin condensation. Arrows represent cells exhibiting apoptosis. The bar represents $150 \mu \mathrm{m}$. " $\mathrm{P}<0.05$ vs. the control cells; ${ }^{* *} \mathrm{P}<0.01$ vs. the control cells.
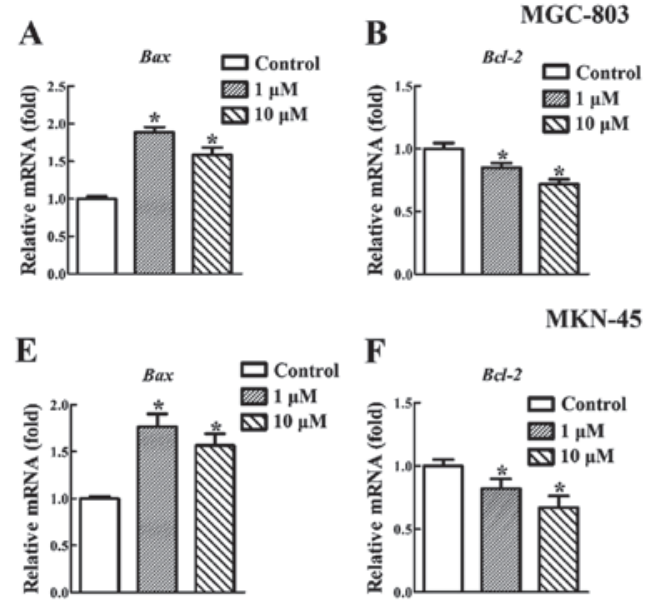

C
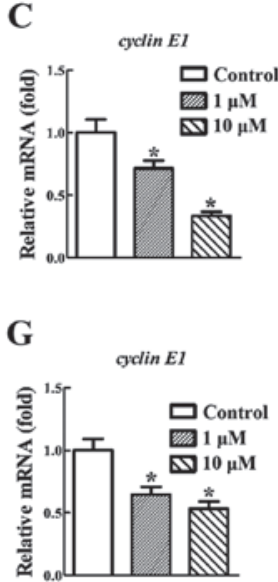
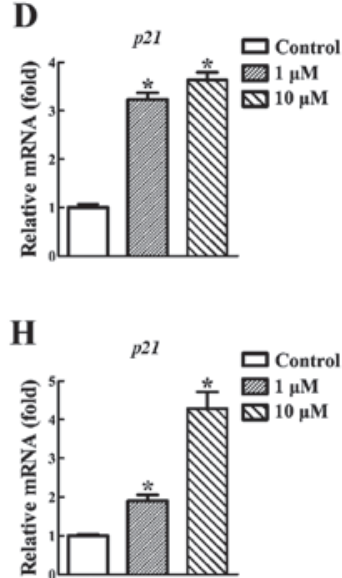

I

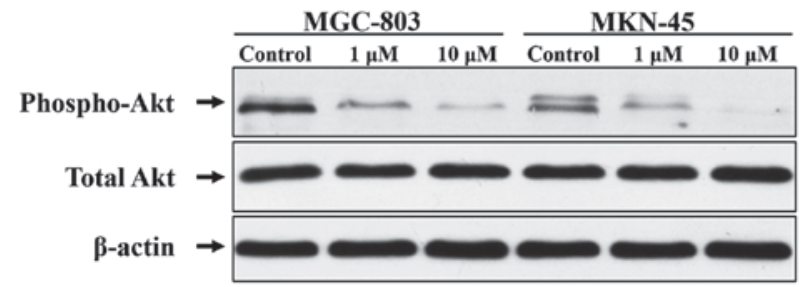

Figure 5. Relative gene and protein expression under the treatment of deguelin. After treatment with deguelin (1 and $10 \mu \mathrm{M})$ for $48 \mathrm{~h}$, MGC-803 cells were subjected to real-time qPCR to detect the effects of deguelin on the gene expression levels of (A) Bax, (B) Bcl-2, (C) cyclin E1 and (D) p21, and MKN-45 cells were subjected to real-time qPCR to detect the effects of deguelin on the gene expression levels of (E) Bax, (F) Bcl-2, (G) cyclin E1 and (H) p21. (I) MGC-803 and MKN-45 cells were treated with increasing doses of deguelin $(0,1$ and $10 \mu \mathrm{M})$ for $6 \mathrm{~h}$ and harvested for western blot (WB) analysis to assess the p-Akt signaling as indicated. ${ }^{*} \mathrm{P}<0.05$ compared to dimethyl sulfoxide (DMSO) control of each cell line. 


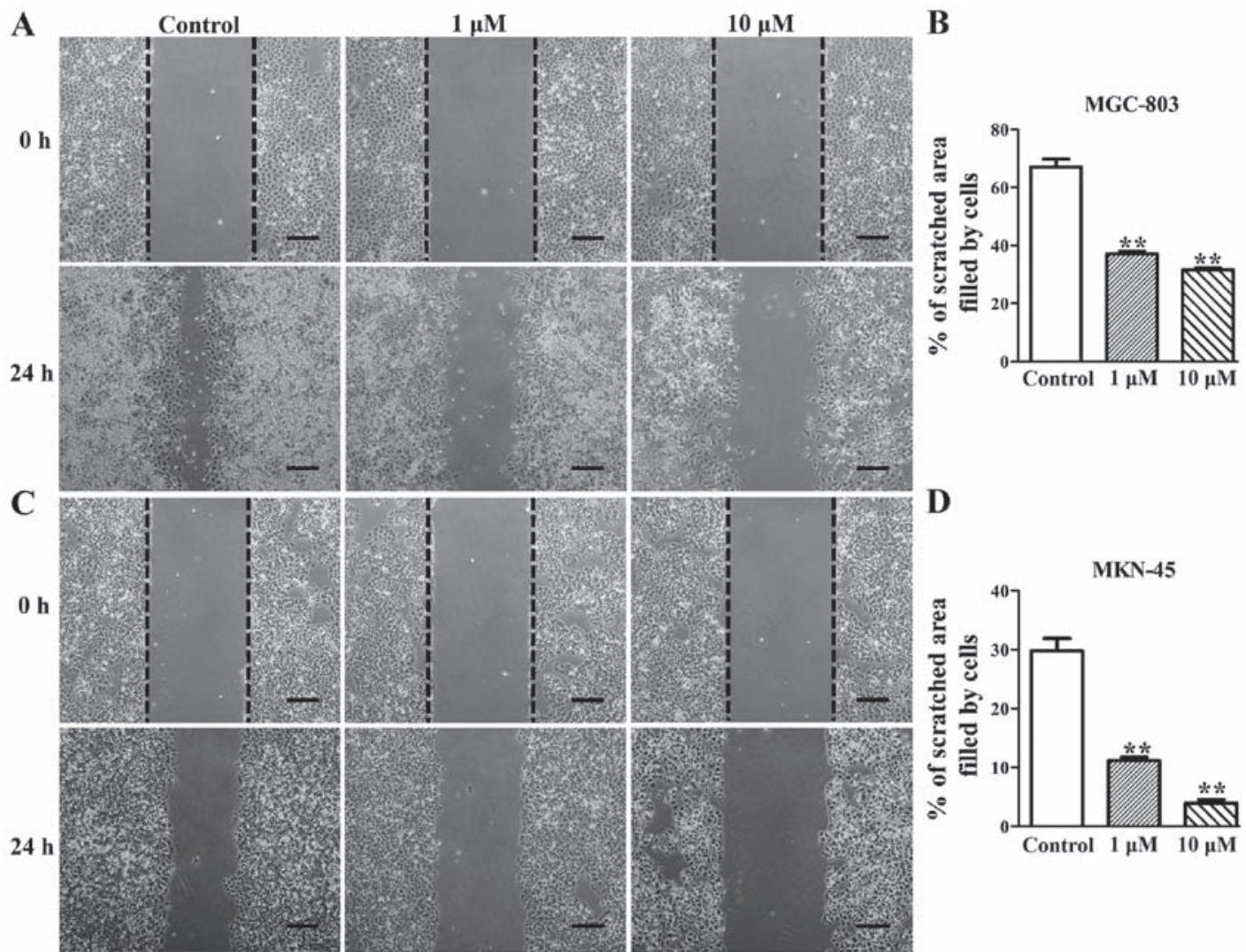

Figure 6. Deguelin inhibits the migration of MGC-803 and MKN-45 cells in vitro. Cells were manually scratched with a $200 \mu 1$ pipette tip (black dash lines) and then incubated with or without deguelin for $24 \mathrm{~h}$. (A and B) The scratched areas filled by migrated MGC-803 cells were observed at $24 \mathrm{~h}$ post-scratching and was quantified using IPP software. (C and D) The scratched areas filled by migrated MKN-45 cells were observed at $24 \mathrm{~h}$ post-scratching and was quantified using IPP software. The bar represents $250 \mu \mathrm{m} .{ }^{* *} \mathrm{P}<0.01$ compared to DMSO control of each cell line.
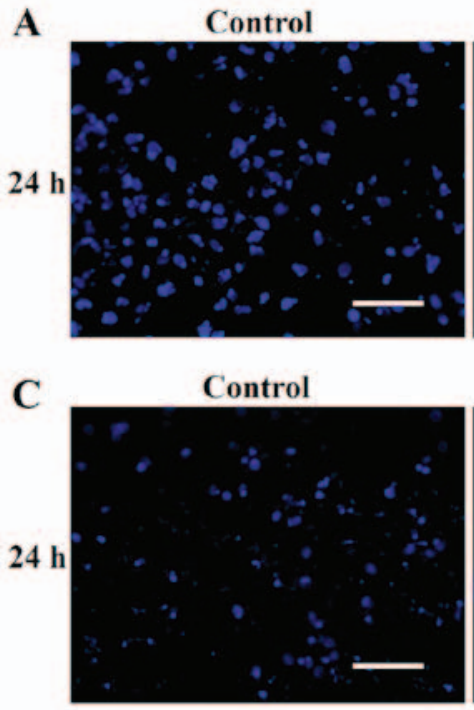

$1 \mu \mathrm{M}$
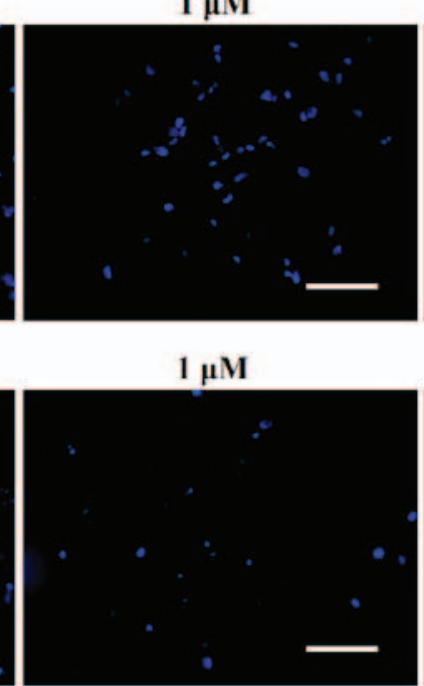

$10 \mu \mathrm{M}$
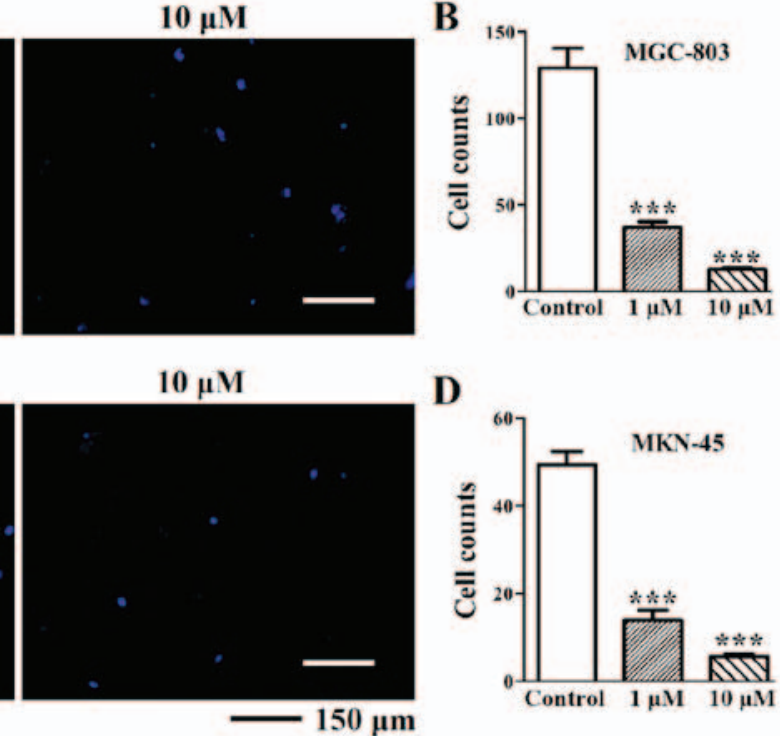

D

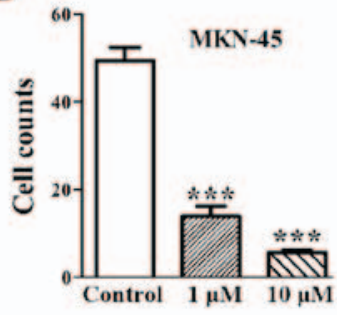

Figure 7. Deguelin inhibits the invasion of MGC- 803 and MKN-45 cells in vitro. The MGC-803 and MKN-45 cells were treated with deguelin, and the inhibitory effect of deguelin on their invasion ability was evaluated by Transwell assay. (A and C) Representative images show the invasive cells after a 24-h deguelin treatment. The invasive cells were visualized by imaging the DAPI-labeled nuclei. (B and D) The invasive cell number of each cell line was quantified and counted in three random fields. All the experiments were repeated in three independent experiment. The bar represents $150 \mu \mathrm{m}$. ${ }^{* * *} \mathrm{P}<0.001$ compared to the dimethyl sulfoxide (DMSO) control.

by upregulating the pro-apoptotic gene $B a x$ and downregulating the anti-apoptotic gene $\mathrm{Bcl}-2$ in a dose-dependent manner (Fig. 5A, B, E and F). In conclusion, deguelin induced gastric cancer cell lines apoptosis via two pathways including the regulation of $\mathrm{Bax} / \mathrm{Bcl}-2$ ratio and inhibition of Akt activation. 
The motility of gastric cancer cells plays a critical role in development of metastasis. A number of reported studies have demonstrated the effect of deguelin on the migration and invasion of different cancer types $(25,42-44)$. Hu et al found that the treatment of deguelin inhibited lung cancer migration via downregulating Akt and the MAPK pathway (25). In another study, deguelin inhibited the migration and invasion of human osteosarcoma cells via the inhibition of MMP-2/9 in vitro by inhibiting the expression of GRB2, FAK and RhoA (44). However, the effects of deguelin on motility of gastric cancer MGC-803 and MKN-45 cell lines have not been reported. As shown in Figs. 6 and 7, the results showed that deguelin reduced cell migration and invasion of gastric cancer MGC-803 and MKN-45 cell lines in vitro. Therefore, deguelin would be a useful candidate to suppress cancer progression and metastasis. Based on the literature, deguelin suppressed the migration and invasion of cancer cells by complicated mechanisms such as reducing the expression and inactivation of FAK, RhoA-ROCK, MAPK and Akt. The mechanism that occurred in the effect of deguelin on the migration and invasion of gastric cancer cells need further investigation.

In conclusion, this study demonstrated that deguelin exhibited anticancer effect by inhibiting cell proliferation, causing cell cycle arrest, inducing apoptosis and suppressing cell migration and invasion of human gastric cancer in vitro. To provide a guide for further clinical trials, more studies on the precise mechanism of deguelin treatment of gastric cancer, however, are still needed. Since a number of reported animal studies have proved the antitumor activity of deguelin at doses of 3-5 mg/kg using xenograft models of different cancer types in vivo $(24,43,45)$. These bionic models as well as our study warrant further in vivo investigations of deguelin efficacy. Collectively, deguelin may represent a promising anticancer agent capable of combating the progression and metastasis of gastric cancer.

\section{Acknowledgements}

The authors would like to thank the Shanghai Key Laboratory of Tissue Engineering for its technical assistance.

\section{Funding}

This study was supported by grants from the Scientific Research Foundation of Traditional Chinese Medicine of Shanghai (2014JP013A, to PW) and the Research Innovation Program of Shanghai Municipal Education Commission (09yz79, to SG).

\section{Availability of data and material}

The datasets used and analyzed during the current study are available from the corresponding author on reasonable request.

\section{Authors' contributions}

WK and $\mathrm{XZ}$ performed the experiments and wrote the manuscript. SG and PW designed the experimental plan and analyzed the data. All authors read and approved the final manuscript.

\section{Ethics approval and consent to participate}

Not applicable.

\section{Consent for publication}

Not applicable.

\section{Competing interests}

The authors declare that they have no competing interests.

\section{References}

1. Brenner H, Rothenbacher D and Arndt V: Epidemiology of stomach cancer. Methods Mol Biol 472: 467-477, 2009.

2. Orditura M, Galizia G, Sforza V, Gambardella V, Fabozzi A, Laterza MM, Andreozzi F, Ventriglia J, Savastano B, Mabilia A, et al: Treatment of gastric cancer. World J Gastroenterol 20: 1635-1649, 2014

3. Tian WY, Chen WC, Li R and Liu L: Markers CD40, VEGF, AKT, PI3K, and S100 correlate with tumor stage in gastric cancer. Onkologie 36: 26-31, 2013

4. Ye B, Jiang LL, Xu HT, Zhou DW and Li ZS: Expression of PI3K/AKT pathway in gastric cancer and its blockade suppresses tumor growth and metastasis. Int J Immunopathol Pharmacol 25: 627-636, 2012.

5. Sukawa Y, Yamamoto H, Nosho K, Kunimoto H, Suzuki H, Adachi Y, Nakazawa M, Nobuoka T, Kawayama M, Mikami M, et al: Alterations in the human epidermal growth factor receptor 2-phosphatidylinositol 3-kinase-v-Akt pathway in gastric cancer. World J Gastroenterol 18: 6577-6586, 2012.

6. Wu W, Hai Y, Chen L, Liu RJ, Han YX, Li WH, Li S, Lin S and Wu XR: Deguelin-induced blockade of PI3K/protein kinase B/MAP kinase signaling in zebrafish and breast cancer cell lines is mediated by downregulation of fibroblast growth factor receptor 4 activity. Pharmacol Res Perspect 4: e00212, 2016.

7. Chun KH, Kosmeder JW II, Sun S, Pezzuto JM, Lotan R, Hong WK and Lee HY: Effects of deguelin on the phosphatidylinositol 3-kinase/Akt pathway and apoptosis in premalignant human bronchial epithelial cells. J Natl Cancer Inst 95: 291-302, 2003.

8. Thamilselvan V, Menon M and Thamilselvan S: Anticancer efficacy of deguelin in human prostate cancer cells targeting glycogen synthase kinase-3 $\beta / \beta$-catenin pathway. Int J Cancer 129 : 2916-2927, 2011.

9. Yan B, Zhao D, Yao Y, Bao Z, Lu G and Zhou J: Deguelin induces the apoptosis of lung squamous cell carcinoma cells through regulating the expression of galectin-1. Int J Biol Sci 12: 850-860, 2016.

10. Murillo G, Salti GI, Kosmeder JW II, Pezzuto JM and Mehta RG: Deguelin inhibits the growth of colon cancer cells through the induction of apoptosis and cell cycle arrest. Eur J Cancer 38: 2446-2454, 2002.

11. Wang Y, Ma W and Zheng W: Deguelin, a novel antitumorigenic agent targeting apoptosis, cell cycle arrest and anti-angiogenesis for cancer chemoprevention. Mol Clin Oncol 1: 215-219, 2013.

12. Baba Y, Fujii M, Maeda T, Suzuki A, Yuzawa S and Kato Y: Deguelin induces apoptosis by targeting both EGFR-Akt and IGF1R-Akt pathways in head and neck squamous cell cancer cell lines. BioMed Res Int 2015: 657179, 2015.

13. Mehta RR, Katta H, Kalra A, Patel R, Gupta A, Alimirah F, Murillo G, Peng X, Unni A, Muzzio M, et al: Efficacy and mechanism of action of Deguelin in suppressing metastasis of 4T1 cells. Clin Exp Metastasis 30: 855-866, 2013.

14. Karimi P, Islami F, Anandasabapathy S, Freedman ND and Kamangar F: Gastric cancer: Descriptive epidemiology, risk factors, screening, and prevention. Cancer Epidemiol Biomarkers Prev 23: 700-713, 2014.

15. Clarke JS, Cruze K, El Farra S and Longmire WP Jr: The natural history and results of surgical therapy for carcinoma of the stomach. An analysis of 250 cases. Am J Surg 102: 143-152, 1961.

16. Janunger KG, Hafström L, Nygren $P$ and Glimelius B; SBU-group. Swedish council of technology assessment in health care: A systematic overview of chemotherapy effects in gastric cancer. Acta Oncol 40: 309-326, 2001. 
17. Zhao H, Jiao Y and Zhang Z: Deguelin inhibits the migration and invasion of lung cancer A549 and H460 cells via regulating actin cytoskeleton rearrangement. Int J Clin Exp Pathol 8: 15582-15590, 2015.

18. Yi S, Wen L, He J, Wang Y, Zhao F, Zhao J, Zhao Z, Cui G and Chen Y: Deguelin, a selective silencer of the NPM1 mutant, potentiates apoptosis and induces differentiation in AML cells carrying the NPM1 mutation. Ann Hematol 94: 201-210, 2015.

19. Murillo G, Peng X, Torres KE and Mehta RG: Deguelin inhibits growth of breast cancer cells by modulating the expression of key members of the Wnt signaling pathway. Cancer Prev Res (Phila) 2: 942-950, 2009.

20. Xiong JR and Liu HL: Regulatory effects of deguelin on proliferation and cell cycle of Raji cells. J Huazhong Univ Sci Technolog Med Sci 33: 491-495, 2013

21. Xiong Y, Hannon GJ, Zhang H, Casso D, Kobayashi R and Beach D: p21 is a universal inhibitor of cyclin kinases. Nature 366: 701-704, 1993

22. Okuyama T, Maehara Y, Kabashima A, Takahashi I, Kakeji Y and Sugimachi K: Combined evaluation of expressions of p53 and p21 proteins as prognostic factors for patients with gastric carcinoma. Oncology 63: 353-361, 2002.

23. Radhakrishnan SK, Feliciano CS, Najmabadi F, Haegebarth A, Kandel ES, Tyner AL and Gartel AL: Constitutive expression of E2F-1 leads to p21-dependent cell cycle arrest in S phase of the cell cycle. Oncogene 23: 4173-4176, 2004.

24. Mehta R, Katta H, Alimirah F, Patel R, Murillo G, Peng X, Muzzio M and Mehta RG: Deguelin action involves c-Met and EGFR signaling pathways in triple negative breast cancer cells. PLoS One 8: e65113, 2013.

25. Hu J, Ye H, Fu A, Chen X, Wang Y, Chen X, Ye X, Xiao W, Duan X, Wei Y, et al: Deguelin - an inhibitor to tumor lymphangiogenesis and lymphatic metastasis by downregulation of vascular endothelial cell growth factor-D in lung tumor model. Int J Cancer 127: 2455-2466, 2010.

26. Peng XH, Karna P, O'Regan RM, Liu X, Naithani R, Moriarty RM, Wood WC, Lee HY and Yang L: Downregulation of inhibitor of apoptosis proteins by deguelin selectively induces apoptosis in breast cancer cells. Mol Pharmacol 71: 101-111, 2007.

27. Chen Y, Wu Q, Cui GH, Chen YQ and Li R: Deguelin blocks cells survival signal pathways and induces apoptosis of HL-60 cells in vitro. Int J Hematol 89: 618-623, 2009.

28. Bortul R, Tazzari PL, Billi AM, Tabellini G, Mantovani I, Cappellini A, Grafone T, Martinelli G, Conte R and Martelli AM: Deguelin, A PI3K/AKT inhibitor, enhances chemosensitivity of leukaemia cells with an active PI3K/AKT pathway. Br J Haematol 129: 677-686, 2005.

29. Chu ZH, Liang XH, Zhou XL, Huang RF, Zhan Q and Jiang JW: Effects of deguelin on proliferation and apoptosis of MCF-7 breast cancer cells by phosphatidylinositol 3-kinase/Akt signaling pathway. Zhong Xi Yi Jie He Xue Bao 9: 533-538, 2011 (In Chinese).

30. Chiu TH, Lan KY, Yang MD, Lin JJ, Hsia TC, Wu CT, Yang JS Chueh FS and Chung JG: Diallyl sulfide promotes cell-cycle arrest through the p53 expression and triggers induction of apoptosis via caspase- and mitochondria-dependent signaling pathways in human cervical cancer Ca Ski cells. Nutr Cancer 65 505-514, 2013

31. Wu J, Yang J, Liu Q, Wu S, Ma H and Cai Y: Lanthanum induced primary neuronal apoptosis through mitochondrial dysfunction modulated by $\mathrm{Ca}^{2+}$ and Bcl-2 family. Biol Trace Elem Res 152 $125-134,2013$
32. van Gurp M, Festjens N, van Loo G, Saelens $X$ and Vandenabeele P: Mitochondrial intermembrane proteins in cell death. Biochem Biophys Res Commun 304: 487-497, 2003.

33. Scorrano L and Korsmeyer SJ: Mechanisms of cytochrome $c$ release by proapoptotic BCL-2 family members. Biochem Biophys Res Commun 304: 437-444, 2003.

34. Kuwana T, Mackey MR, Perkins G, Ellisman MH, Latterich M, Schneiter R, Green DR and Newmeyer DD: Bid, Bax, and lipids cooperate to form supramolecular openings in the outer mitochondrial membrane. Cell 111: 331-342, 2002.

35. Crompton M: Bax, Bid and the permeabilization of the mitochondrial outer membrane in apoptosis. Curr Opin Cell Biol 12: 414-419, 2000.

36. Wei MC, Zong WX, Cheng EH, Lindsten T, Panoutsakopoulou V, Ross AJ, Roth KA, MacGregor GR, Thompson CB and Korsmeyer SJ: Proapoptotic BAX and BAK: A requisite gateway to mitochondrial dysfunction and death. Science 292: 727-730, 2001.

37. Kim R, Emi M and Tanabe K: Role of mitochondria as the gardens of cell death. Cancer Chemother Pharmacol 57: 545-553, 2006.

38. Green DR and Reed JC: Mitochondria and apoptosis. Science 281: 1309-1312, 1998

39. Gross A, McDonnell JM and Korsmeyer SJ: BCL-2 family members and the mitochondria in apoptosis. Genes Dev 13 1899-1911, 1999.

40. Ghribi O, Herman MM, Spaulding NK and Savory J: Lithium inhibits aluminum-induced apoptosis in rabbit hippocampus, by preventing cytochrome $c$ translocation, $\mathrm{Bcl}-2$ decrease, Bax elevation and caspase-3 activation. J Neurochem 82: 137-145, 2002.

41. Rossé T, Olivier R, Monney L, Rager M, Conus S, Fellay I, Jansen B and Borner C: Bcl-2 prolongs cell survival after Bax-induced release of cytochrome $c$. Nature 391: 496-499, 1998.

42. Liu YP, Lee JJ, Lai TC, Lee CH, Hsiao YW, Chen PS, Liu WT, Hong CY, Lin SK, Ping Kuo MY, et al: Suppressive function of low-dose deguelin on the invasion of oral cancer cells by downregulating tumor necrosis factor alpha-induced nuclear factor-kappa B signaling. Head Neck 38 (Suppl 1): E524-E534, 2016.

43. Boreddy SR and Srivastava SK: Deguelin suppresses pancreatic tumor growth and metastasis by inhibiting epithelial-tomesenchymal transition in an orthotopic model. Oncogene 32 : 3980-3991, 2013

44. Shang HS, Chang JB, Lin JH, Lin JP, Hsu SC, Liu CM, Liu JY, Wu PP, Lu HF, Au MK, et al: Deguelin inhibits the migration and invasion of U-2 OS human osteosarcoma cells via the inhibition of matrix metalloproteinase-2/-9 in vitro. Molecules 19: 16588-16608, 2014.

45. Yang YL, Ji C, Bi ZG, Lu CC, Wang R, Gu B and Cheng L: Deguelin induces both apoptosis and autophagy in cultured head and neck squamous cell carcinoma cells. PLoS One 8: e54736, 2013.

This work is licensed under a Creative Commons Attribution-NonCommercial-NoDerivatives 4.0 International (CC BY-NC-ND 4.0) License. 